\title{
CHEMICAL, NUTRITIONAL AND BIOLOGICAL EVALUATION OF NUTRITIONAL SUPPLEMENT PREPARED WITH GERMINATED DATE PALM SEEDS POWDER AND OTHER TRADITIONAL FOOD ITEMS
}

\author{
Abdelrasoul, E.A. and Amani A. A. Metwalli \\ Food Technol. Res. Inst., Agric. Res. Cent., Sakha, Egypt
}

\begin{abstract}
Germinated date palm seeds powder was employed, together with soybean flour, sugar, banana meal and maize meal for the preparation of a nutritional supplement. 12-day old male Wister rates were fed diets containing the supplement as a protein source, both with and without soybean flour; casein diets with 10 or $7 \%$ protein served as respective controls. Protein efficiency ratio (PER), net protein utilization (NPU), net protein retention (NPR) and digestibility were determined. Blood biochemical parameters (triglycerides, total cholesterol, LDL-cholesterol and HDLCholesterol were also measured in the animals and showed that all rats were in good health condition at the end of experiment. The obtained results for PER, NPU and NPR indicated that the supplement prepared with germinated date palm seeds powder was a good protein source, especially when soybean flour was added.

Keywords:Germination, data palm seeds, biological evaluation, and supplement.
\end{abstract}

\section{INTRODUCTION}

The prevalence of malnutrition among low income populations in world has led to the utilization of "alternative" food ingredients, such as powdered cassava and sugar beet leaves, date palm seeds, wheat and rice bran and powdered egg shell, among others, as nutritional supplements (Pellet and Young, 1980). Egypt is one of important countries in date world production which produced 1049646 tons reported by FAO, (2005). The Egyptian date represented about $16.5 \%$ of the total world production. Date seeds represent $10-15 \%$ of date fruits. At presented time there are 16 factories for date palm processing and some other will be build in the future Salah, (2005). All these factories have a mass production of date palm seed which comes as waste product during date processing. If these seeds were exploited well, it could play a good role in the national income. Some studies, have been done on date palm seeds, Sumianah et al., (1984) who studied the effect of germination at $35-36^{\circ} \mathrm{C}$ for 22 and 52 days on three cultivars (Razaz, Khalas and Beshi). They found that crude protein, fats, total carbohydrates and starch decreased by germination but crude fiber, ash, total soluble carbohydrate and reducing sugars increased during germination. Also, the germination for 52 days was useful as a pretreatment of date palm seeds for animals feeding. Devshony et al., (1992) obtained on average values for the four date palm seeds cultivars on a dry-weight basis: protein $5.60 \%$, oil $2.15 \%$, fiber $16.13 \%$ and ash $1.13 \%$. Analysis of the mineral elements in the ash were: $\mathrm{Ca}, 1.55 \%$; $\mathrm{Na}, 0.97 ; \mathrm{Mg}, 8.07 \% ; \mathrm{K}, 27.60 \% ; \mathrm{Fe}$ $0.73 \% ; \mathrm{Cu}, 0.13 \%$ and $\mathrm{Mn}, 0.08 \%$. Diet contained $1.5 \%$ date seed fibers is 
the most appropriate because of its action in reducing LDL-cholesterol, total cholesterol and triglyceride (Salah, 2005). However, such level (1.5\%) of date seeds fiber had no effect in HDL-cholesterol level.

The objectiveof this study was to use germinated date palm seeds as a waste for preparation nutritional supplement.

\section{MATERIALS AND METHODS}

\section{Materials:}

Siwi date palm seeds were obtained from the factory dates of Borg Elarab City, Alexandria. Egypt. Soya been flour was obtained from Food Technology Research Institute, Agriculture Research Center, Giza, Egypt. Sugar, banana meal and maize meal were obtained from local market at Kafr Elsheikh Governorate. All chemicals were obtained from Elgomhoria Co., Tanta, Egypt.

\section{Methods:}

Date seeds germination:

Date palm seeds were collected, washed, dried by air oven then wetted by water covered by a wet cloth and then left at ambient temperature for 40 days keeping the cloth in wet nature. The germinated seeds with the same characteristics were washed, dried by fan oven, then crushed and grinded to powder. Every fraction was placed in a jar and stored in deep freezer $\left(-18^{\circ} \mathrm{C}\right)$ until chemical analysis.

\section{Nutritional supplements:}

The proposed supplements were prepared by mixing thoroughly its ingredients and their composition is shown in Table 1.

Table (1): Composition of the germinated date palm seeds powder supplements with (A) and without (B) soybean flour (values in $\% \mathbf{w} / \mathbf{w})$.

\begin{tabular}{|l|c|c|}
\hline Ingredients & A & B \\
\hline Germinated date palm seeds powder & 45 & 60 \\
Soybean flour & 15 & 00 \\
Sugar & 10 & 10 \\
Banana meal & 20 & 20 \\
Maize meal & 10 & 10 \\
\hline Total & 100 & 100 \\
\hline
\end{tabular}

Chemical analysis:

Moisture, protein, fat, ash and crude fibers content were determined according to A.O.A.C. (1990).

Reducing sugars were extracted by ethanol $80 \%$ and determined by arsinomolybdates and Somogi cupper reagent as described by Somogi (1952) and Nelson (1974). Starch was determined as reported by Ranganna (1977). Total free phenols were determined by using folin-Denis reagent as described by Swain and Hillis (1959). Amino acids were fractionated by high 
performance amino acid analyzer. Anthocyanidin was measured as reported by Barreveld (1993).

Biological assay:

Animals and diets:

21-day old male Wister rats (weight $80-90 \mathrm{~g}$ ) were obtained from house of experimental animals, Food Technology Research Institute, Agriculture Research Center, Giza, Egypt.

\section{Experimental design:}

The tested rats were divided randomly into five groups (each of 20 rats).

Groups were:

A: rats fed on control $10 \%$.

B: rats fed on $7 \%$.

C: rats fed on protein-free.

D: rats fed on experimental with soybean flour.

E: rats fed on experimental without soybean flour.

All groups were housed in individual wire cages and fed the diets shown in Table (2). Diets were approximately isocaloric and the protein contents of the control diets were in consonance with those of the experimental ones, that is 10 and $7 \% \mathrm{w} / \mathrm{w}$ were controls for respectively experimental diet with soybean flour and experimental without it. The chemical composition of the diets is shown in Table (3).

Table (2): Diets Composition.

\begin{tabular}{|l|c|c|c|c|c|}
\hline Ingredients & A & B & C & D & E \\
\hline Casein $^{1}$ & 12.50 & 8.75 & - & - & - \\
Salt mixture $^{2}$ & 5.00 & 5.00 & 5.00 & 5.00 & 5.00 \\
Vitamin mixture $^{2}$ & 1.00 & 1.00 & 1.00 & 1.00 & 1.00 \\
Soybean oil & 8.00 & 8.00 & 8.00 & 6.00 & 6.00 \\
Choline & 0.04 & 0.04 & 0.04 & 0.04 & 0.04 \\
Cellulose & 100 & 1.00 & 1.00 & 1.00 & 1.00 \\
Corn starch & 72.46 & 76.21 & 84.96 & 11.21 & - \\
Supplement & - & - & - & 75.75 & 86.96 \\
\hline
\end{tabular}

$1=$ Casein contained $80 \% \mathrm{w} / \mathrm{w}$ protein

${ }^{2}=$ According to AOAC, 1975

Table (3): Chemical composition of diets.

\begin{tabular}{|l|c|c|c|c|c|}
\hline Component & A & B & C & D & E \\
\hline Protein & 10.24 & 7.25 & 0.26 & 9.62 & 6.64 \\
Ash & 5.31 & 5.19 & 5.11 & 6.87 & 6.67 \\
Fat & 7.99 & 8.11 & 8.06 & 7.30 & 7.34 \\
Moisture & 10.69 & 10.49 & 10.31 & 6.81 & 6.68 \\
Carbohydrate & 64.81 & 67.87 & 75.50 & 68.13 & 71.43 \\
Fiber & 1.03 & 1.02 & 1.02 & 1.20 & 1.25 \\
\hline
\end{tabular}

\section{Biological:}


Biological parameters were determined as described by Pellet and Young (1980). Food consumption and weight gain by the animals were recorded weekly.

Net protein utilization (NPU) was calculated by the difference in carcass nitrogen (as expressed by nitrogen in left hind leg- between rats fed the test diets and those fed a protein-free diet. After 10 days of experiment, half of the rats were scarified and the left hind leg was excised and weighted. Nitrogen was determined. The following equation was used for NPU evaluation:

$$
\mathrm{NPR}=\frac{\text { weight gain }(\text { test group })+\text { weight loss }(\text { protein }+ \text { free group })}{\text { Protein ingested by test group }}
$$

Protein efficiency ratio (PER) was calculated by the ratio of weight gain $(\mathrm{g}) /$ protein intake $(\mathrm{g})$, after 28 days for each of the remaining animals.

Digestibility (D) from the $14^{\text {th }}$ to $21^{\text {st }}$ day of experiment, the feces were collected daily, dried at $105^{\circ} \mathrm{C}$, weighted and its nitrogen content determined. $D$ was evaluated through the

$D=$ nitrogen intake-fecal nitrogen/nitrogen intake $\times 100$

Biochemical assay:

Total cholesterol contents of plasma $(\mathrm{mmol} / \mathrm{L})$ were detemriend enzymatically (Richmond, 1973) using Huan kits (Human Gesellschaft für, Biochemcial and Diagnostica mbh Germany). The HDL-Cholesterol, LDLCholesterol and triglycerides $(\mathrm{mmol} / \mathrm{L})$ were also measured enzymatically (Trinder, 1969), with kits (Human Biochemical Co, USA).

Statistical analysis:

All data expressed as means + significant differences among the groups were determined by on-way analysis of variance using the SPSS statistical analysis program. Statistical significance was considered at $(P<$ 0.05).

\section{RESULTS AND DISCUSSION}

Chemical composition of date palm seeds before and after germination:

Table (4) showed that reducing sugars of germinated seeds increased, but the starch was decreased. These increasing and decreasing might be resulted from the effect of specific enzymes of special substances (amylase on starch and invertase on sucrose). The crude protein, fat, ash and crude fiber were decreased to $10.7,4.6,0.9$ and $4.4 \%$, respectively. Total free phenols were decreased after germination, which might be related to consumption of simple phenols through the formation of other complicated and high molecular weight compounds, which have a good role in the new parts of seed growth during germination. Previous results are obtained by similar to the results of (Sumianah et al.,, 1984). Anthocyanidin was observed that dried date seeds content of their dropped from 1.23 to $0.68 \%$ by germination. 
Table (4): Chemical composition of date palm seeds before and after germination (\% dry wet.).

\begin{tabular}{|l|c|c|}
\hline Component & Before & After \\
\hline Dry matter (\%) & 90.72 & 55.63 \\
Protein & 6.76 & 6.04 \\
Fat & 10.21 & 9.74 \\
Ash & 1.13 & 1.12 \\
Total carbohydrate & 81.90 & 83.10 \\
Starch & 18.31 & 16.94 \\
Reducing sugars & 5.53 & 6.15 \\
Crude fiber & 16.66 & 15.93 \\
Total free phenols & 3.54 & 2.30 \\
Anthocyandin & 1.23 & 0.68 \\
\hline
\end{tabular}

\section{Amino acids composition of date palm seeds protein:}

Amino acids were fractioned (Table 5), it was found that theronine content of date seeds was more than human requirements, this amino acid decreased by germination to $2.00 \mathrm{~g} / 100 \mathrm{~g}$ protein. Valine increased by germination to be near the requirements, on the other hand cysteine and methionine together was more than the requirements during germination. Isolleucine content was more than half of the requirements in dried date seeds and during germination. Leucine increased by germination. The leucine, (tyrosine and phenylalanine) and lysine contents in dried and germinated date seed represented more than $70.66 \%$ and $70 \%$ of requirements (FAO/WHO, 1973). Generally, glutamic, aspartic and arginine the non essential amino acids represented the maximal percentage of total protein.

Table (5): Amino acids composition of date palm seeds protein before and after germination $(\mathrm{g} / 100 \mathrm{~g})$.

\begin{tabular}{|c|c|c|c|}
\hline \\
\hline Amino acid & Before & After & FAO/WHO (1973) \\
\hline \multicolumn{4}{|c|}{ Essential amino acids: } \\
\hline Lysine & 4.31 & 4.86 & 5.5 \\
\hline Threonine & 4.96 & 2.00 & 4.0 \\
\hline Valine & 3.71 & 4.81 & 5.0 \\
\hline Methionine & 2.87 & 1.98 & \\
\hline Cysteine & 2.86 & 1.79 & 3.5 \\
\hline Isoleucine & 2.81 & 2.84 & \\
\hline Leucine & 5.71 & 5.94 & 4.0 \\
\hline Phenylalanine & 3.21 & 3.61 & 7.0 \\
\hline Tyrosine & 0.71 & 0.66 & 7 \\
\hline Trptophan & - & - & 6.0 \\
\hline \multirow{2}{*}{\multicolumn{4}{|c|}{ Non essential amino acids: }} \\
\hline & & & \\
\hline Asparatic acid & 10.51 & 12.73 & - \\
\hline Serine & 5.23 & 3.53 & - \\
\hline Glutamic acid & 26.00 & 27.32 & - \\
\hline Proloine & - & - & - \\
\hline Glysine & 5.21 & 5.00 & - \\
\hline Alanien & 4.11 & 4.86 & - \\
\hline Histidine & 1.73 & 1.89 & - \\
\hline Arginine & 10.91 & 8.93 & - \\
\hline
\end{tabular}




\section{Food ingestion, weight gain and feces weight of experimental animals groups:}

Data relative to food ingestion, weight gain and feces weight are depicted in Table 6 . Animals fed the diets containing the supplements, both with and without soybean, ingested as much food as did the control $10 \%$ protein group and a bit more than the $7 \%$ protein control. On the other hand, weight gain was statistically similar when experimental groups were compared with their respectively controls. Nevertheless, when food efficiency (weight gain/food ingestion $\times 10$ ) was considered, animals receiving the supplements showed values comparable to their respective control $(24.7 \%$, $22.1 \%, 15.5 \%$ and $11.9 \%$ for control $10 \%$, experimental with soybean, control $7 \%$ and experimental without soybean). The amount of feces excreted by animals that ingested the diets containing the supplements was higher than their respective controls. The weekly recording of food consumption and weight gain showed that the biological assay proceeded without abnormalities. Food efficacy of the diets containing the proposed supplements was similar to their respective control. As expected, fees weight was dependent on the amount of fiber in the diets (Table 3) and on food ingestion (Table 6), with the animals consuming the diet with soybean flour showing the highest value.

Table (6): food ingestion, weight gain and feces weight of rats.

\begin{tabular}{|l|c|c|c|c|c|}
\hline & $\mathbf{A}(\mathbf{g})$ & $\mathbf{B}(\mathbf{g})$ & $\mathbf{C}(\mathbf{g})$ & $\mathbf{D}(\mathbf{g})$ & $\mathbf{E}(\mathbf{g})$ \\
\hline Food ingestion & $328.5+21.8 \mathrm{a}$ & $278.0+42.5 \mathrm{~b}$ & $219.3+9.1 \mathrm{c}$ & $358.1+31.0 \mathrm{a}$ & $323.3+7.3 \mathrm{a}$ \\
Weight gain & $81.3+10.9 \mathrm{a}$ & $43.1+14.1 \mathrm{~b}$ & $18.3+5.3 \mathrm{c}$ & $79.3+1.0 \mathrm{a}$ & $38.5+6.0 \mathrm{~b}$ \\
Feces weight & $15.7+1.8 \mathrm{a}$ & $13.2+2.0 \mathrm{a}$ & $4.3+0.6 \mathrm{~d}$ & $54.9+6.4 \mathrm{~b}$ & $44.1+4.3 \mathrm{C}$ \\
\hline
\end{tabular}

\section{Protein quality:}

In Table 7 are shown that the data obtained when protein quality was biologically assessed. PER values were similar for all groups, except for the one fed the diet containing supplement without soybean flour. On the other hand, rats on all diets present statistically equal values for NPU. In relation to NPR, animals receiving the diet made employing the supplements with or without soybean flour showed patterns statistically similar to their respective (10 and $7 \%$ protein) controls. As regard the digestibility, casein diets were statistically similar to each other and same happened with the experimental diets. It must be stressed that the effect of soybean flour addition was relevant since this item represented only about $11 \% \mathrm{w} / \mathrm{w}$ of the diet but raised the PER value in about $30 \%$. This effect was confirmed by NPR that, taking into account the weight loss by the non-protein group, made similar the values of the experimental animals with their respective controls. As expected, the digestibilities of the 10 and $7 \%$ control diets were similar to each other but higher then that of the experimental ones, probably due to the fiber content of date palm seeds, banana and maize employed in the preparation of the supplements (Eggum, 1995). 
Table (7): Protein efficiency ratio (PER); net protein utilization (NPU); net protein ratio (NPR) and digestibility (D) of rats.

\begin{tabular}{|l|c|c|c|c|}
\hline & $\mathbf{A}$ & $\mathbf{B}$ & $\mathbf{D}$ & $\mathbf{E}$ \\
\hline PER & $2.32+0.19 \mathrm{a}$ & $2.12+0.61 \mathrm{a}$ & $2.31+0.13 \mathrm{a}$ & $1.72+0.32 \mathrm{~b}$ \\
NPU & $103.31+2.61 \mathrm{a}$ & $116.20+27.66 \mathrm{a}$ & $94.83+5.61 \mathrm{a}$ & $95.88+4.31 \mathrm{a}$ \\
NPR & $3.89+0.51 \mathrm{a}$ & $2.61+1.35 \mathrm{~b}, \mathrm{c}$ & $3.82+0.41 \mathrm{a}, \mathrm{c}$ & $1.93+0.71 \mathrm{~b}$ \\
Digestibility & $90.92+0.70 \mathrm{a}$ & $91.33+1.62 \mathrm{a}$ & $73.61+2.13 \mathrm{~b}$ & $70.10+14.3 \mathrm{~b}$ \\
\hline
\end{tabular}

Blood biochemical parameters:

Table 8 shows the biochemical characteristics found in the blood of the animals fed with various diets. As seen, values were statistically similar in all parameters, except for total cholesterol and LDL-cholesterol, which were slightly lesser in the groups that received diet containing supplement without soybean flour as compared to its control (10 and $7 \%$ protein). This results due to high containing of fiber in the diets.

Table (8): Blood biochemical parameters of rats.

\begin{tabular}{|l|c|c|c|c|c|}
\hline & A & B & C & D & E \\
\hline Triglycerides (mmol/L) & $0.952+0.31 \mathrm{a}$ & $924+0.41 \mathrm{a}$ & $0.923+0.33 \mathrm{a}$ & $0.891+0.24 \mathrm{a}$ & $0.869+0.21 \mathrm{a}$ \\
\hline $\begin{array}{l}\text { Total cholesterol } \\
(\mathrm{mmol} / \mathrm{L})\end{array}$ & $1.611+0.13 \mathrm{a}$ & $1.631+0.11 \mathrm{a}$ & $1.50+0.12 \mathrm{a}$ & $1.491+0.22 \mathrm{ab}$ & $1.231+0.12 \mathrm{~b}$ \\
\hline $\begin{array}{l}\text { LDL-Cholesterol } \\
(\mathrm{mmol} / \mathrm{L})\end{array}$ & $0.509+0.31 \mathrm{a}$ & $0.491+0.22 \mathrm{a}$ & $0.489+0.15 \mathrm{a}$ & $0.471+0.13 \mathrm{ab}$ & $0.363+0.24 \mathrm{~b}$ \\
\hline $\begin{array}{l}\mathrm{HDL}-\mathrm{Cholesterol} \\
(\mathrm{mmol} / \mathrm{L})\end{array}$ & $1.125+0.21 \mathrm{a}$ & $1.122+0.20 \mathrm{a}$ & $1.28+0.31 \mathrm{a}$ & $1.121+0.18 \mathrm{a}$ & $1.211+0.20 \mathrm{a}$ \\
\hline
\end{tabular}

In conclusion, the results obtained in the present work indicated that germinated date palm seeds showed a good potential for utilization in nutritional supplements, especially when associated with soybean flour.

\section{REFERENCES}

AOAC (1975). Official Methods of Analysis, Association of Official Analytical Chemists, Washington, D.C.

AOAC (1990). Official Methods of Analysis of the Association of Official Analytical chemists, Arlington, Virginia.

Barreveld, W. (1993). Date palm product (FAO) Agricultural Services Bulletin 101.

Devshony, S.; Eteshola, E. and Shani, A. (1992). Characteristics and some potential applications of date palm (Phoenix dactylifera L.) seeds and seed oil. JAOCS, 69(6): 595-597.

Eggum, B. (1995). The influence of dietary fiber on protein digestion and utilization in monogastrics. Arch. Tierenahr., 48, 89-95.

FAO (2005). Production year book. FAO Production Year Book, Vol. 51 pp.

FAO/WHO (1973). Energy and protein requirements. FAO Nutritional Meeting Report Services. No. 52, WHO Technical Report Series., N. 522, Food and Agriculture Organization, Rome.

Nelson, N. (1974). A photometric adaptation of the somogi methods for determination of glucose. J. Biol. Chemistry, 153: 375-380. 
Pellet, P. and Young, V. (1980). Evaluation of protein quality in experimental animals. In: nutritional Evaluation of protein food. Tokyo. The United Nations University, pp. 41-57.

Ranganna, S. (1997). Manual of analysis of fruit and vegetable products. Tota McGraw-Hill. Publishing Company Limited, New Delhi.

Richmond, W. (1973). Preparation and properties of cholesterol from Nocardia spp. and its application to the enzymatic assay of total cholesterol in serum. Clinical Chemistry, 19: 1350-1365.

Salah, A. (2005). Effect of date palm (Phoenix dactylifera) seed fibers on plasma lipids in rats. J. King Saudi Univ., 17, (2), pp. 117-123.

Somogi, M. (1952). Notes on sugar determination. J. Biol. Chem., 195, 19.

Sumianah, G.; Makki, Y. and Rumne, T. (1984). Changes in the chemical composition of three cultivars of date palm seed during germination. Date Palm J., 3(2): 395-407.

Swain, T. and Hillis, A. (1959). The quantitative analysis of phenolic constituents. J. Sci. Food Agriculture, 10, 65.

Trinder, P. (1969). Enzymatic method of Triglyceroids. Annal of Clinical Biochemical, 6, 24-27.

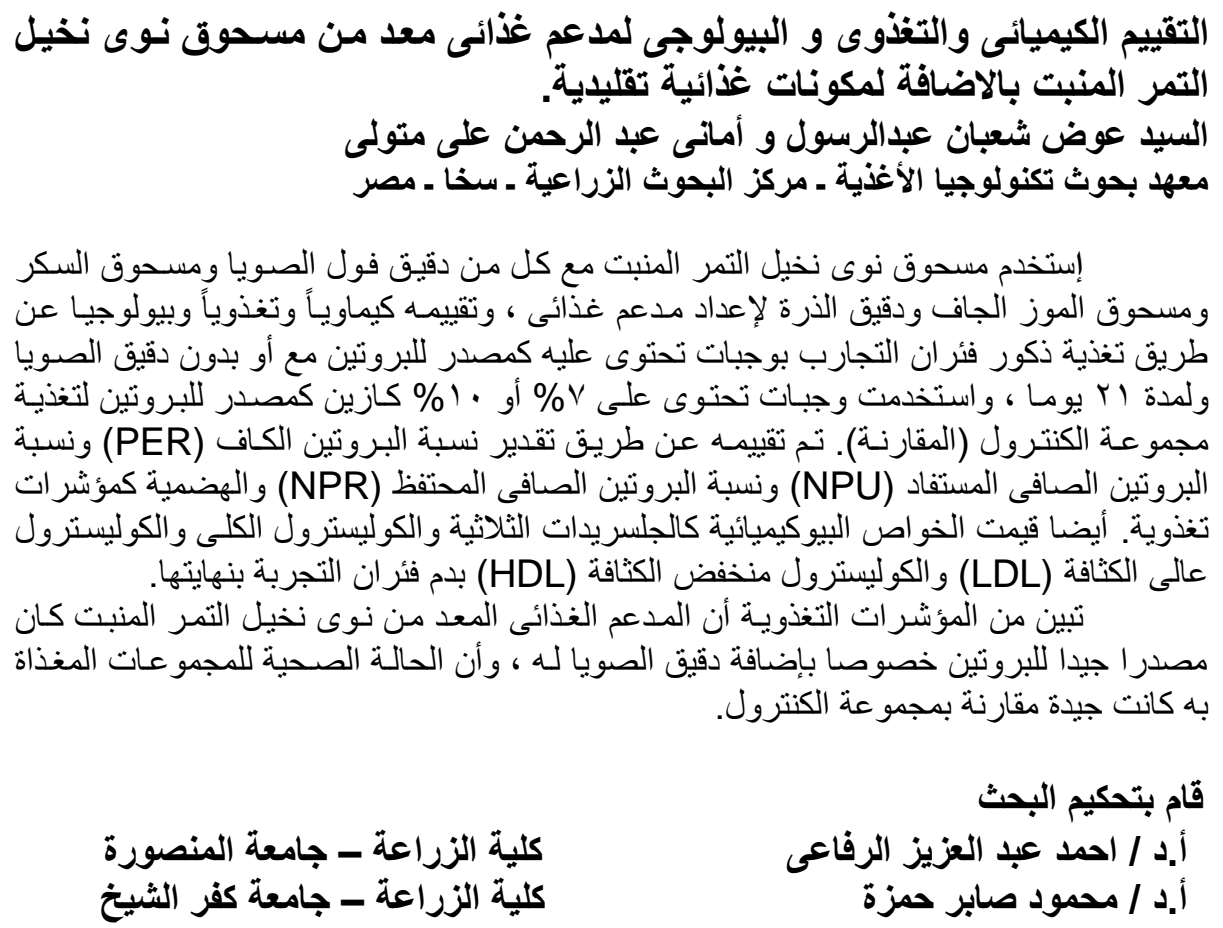

